\title{
実用に即したはんだリサイクル技術
}

\author{
田中 武志 * , 島田 陽三**, 高橋 英志*，田路 和幸*
}

\section{Effective and Low Energy Recycling Method for Solder Paste}

Takeshi TANAKA*, Yozo SHIMADA**, Hideyuki TAKAHASHI*, and Kazuyuki TOHJI*

* 東北大学大学院環境科学研究科（干 980-8579 宮城県仙台市青葉区荒巻字青葉 6-6-20）

**現所属：JAPEX（０59-1364 北海道苫小牧市字沼ノ端134-648）

* Graduate School of Environmental Studies, Tohoku University (6-6-20 Aoba, Aramaki, Aoba-ku, Sendai-shi, Miyagi 980-8579)

**Present: JAPEX (134-648 Numanohata, Tomakomai-shi, Hokkaido 059-1364)

\section{1. 緒 論}

現代社会においてエレクトロニクス産業は大きな発展を 遂げているが，その背景には，集積回路や半導体などの電 子部品の高品質化とともに，微細で緻密な集積回路を作製 するための技術革新がある。集積回路に電子部品を実装す るために欠かせない材料が「はんだ（接合材料）」であり, 古くからスズー鉛合金がはんだとして有効活用されてき た。

スズー鉛合金は安価で融点が低く ${ }^{1)} ，$ 加工が容易で，か つ他の金属との接合性（以降，濡れ性と表記する）が高 (2) など，接合材料としての特性が極めて高いことから， 古来より全世界で利用されてきた。一方で, 科学の発展と ともにさまざまな原料が人体や環境へ与える影響が評価さ れ，さまざまな物質の使用に対する制限や製品に対する使 用が見直されてきた。はんだに含まれる鉛に対しては，自 然界に流出した場合はあらゆる動植物に対し影響を与える こと，慢性的に生体内に取り込まれた場合は神経麻痺など を引き起こすことが報告された ${ }^{3)}$ 。鉛は蓄積型金属である ため，生体内に取り込まれた場合には排出されにくく，摂 取した生物に蓄積される。さらに，鉛を蓄積した生物を上 位捕食者が捕食することにより鉛はさらに蓄積される。こ のような連鎖が繰り返されることにより上位捕食者（われ われ人間などの動植物）ほど濃縮され，蓄積された鉛によ り影響が顕著となる (生物濃縮) ${ }^{4)}$ 。このような背景から, 近年の精密機器業界では製品中に含まれる鉛量を低減させ る鉛フリー化が求められている。電子実装分野に抏いて は, 鉛フリー化を達成するための新規はんだ合金（以降, 鉛フリーはんだ，と表記）の研究開発が精力的に行われ， $\mathrm{Sn}-\mathrm{Ag}$ 系合金（融点： $221^{\circ} \mathrm{C}$ 程度）, $\mathrm{Sn}-\mathrm{Bi}$ 系合金（融点： $138^{\circ} \mathrm{C}$ 程度), $\mathrm{Sn}-\mathrm{Zn}$ 系合金 (融点: $198.5^{\circ} \mathrm{C}$ 程度) などが 報告されている5),6)。このようなさまざまな組成の中で, 特に, $\mathrm{Sn}-\mathrm{Ag}-\mathrm{Cu}$ 系合金（融点: $217^{\circ} \mathrm{C}$ 程度）が $\mathrm{Sn}-\mathrm{Pb}$ 系 合金と代替可能な新規接合材料として広く実用化されてい

$$
る^{7)} \text { 。 }
$$

鉛フリーはんだの実用化とともに，現代の電子実装は， はんだコテとはんだ線を用いたはんだ付けから,“はんだ ペースト”を用いた電子実装へと大きく变化している。 “はんだペースト”はろう接材料の一種であり，スズを主 成分とした金属合金粒子（ $\mathrm{Sn}-\mathrm{Ag}-\mathrm{Cu}$ 粒子など）と松脂や フラックス，ハロゲン活性剂を含んだ有機物成分を混合し たフラックスを混錬して作成したペースト状の材料であ る ${ }^{8)}$ 。この“はんだペースト”はマスクを用いることで電 子基板上の微細部に簡便に塗布可能であり，その上に電子 部品をマウントし，リフロー炉などにより昇温させれば, 基盤と電子部品を実装することが可能である。このよう に，はんだペーストを用いた電子実装は，簡便にかつ一度 に大量に電子部品を実装可能であり, 接合材料の融点を変 化させれば電子基板の両面に実装することが可能であるた め, 現代の精密機器業界では必須の材料となっている。近 年のはんだペーストの使用量増加は著しく, 2003 年度で は5 542 億円の規模であったはんだぺーストが2008年度で は 987 億円と 180\%以上の伸び率を示している。このよう にはんだペーストは現代工業に扔ける重要な電子接合材料 となっている。

しかしながら，はんだペーストは時間の経過（冷暗所保 存で3〜 5 カ月程度）によりフラックス成分が硬化し使用 が不可能となるため，製品の 30～50\%は使用できずに廃 棄されている。これまでは，廃はんだペーストは鉛精錬所 で溶解し，再精製・インゴッド化を経て，再粉体化するこ とでリサイクルされてきた。鉛を含有したはんだペースト は鉛精錬を利用することにより簡便にリサイクル可能で あったが，鉛フリーはんだ化により従来の鉛精錬所でのリ サイクルは不可能となった。また，ほかの精錬所を利用す る場合でも鉛フリー化に伴う高融点化のために消費エネル ギが増加するなど，鉛フリー化によって新たな問題も生じ ている。さらに，鉛フリーはんだを大規模な処理施設が存 在しないため，町工場などの設備が不十分な施設において 
処理されるようになり，その結果として，環境負荷がスや 有害ガスなどを含むガスが周辺に放出する新たな問題が生 じるようになった。そこで，環境にやさしい省エネルギで 効率的に鉛はんだペーストをリサイクル可能な新規技術の 構築が望まれていた。

一般的なはんだリサイクル方法では金属成分のみがリサ イクルされ，有機物成分は精錬中に燃焼除去される。言う までもなく, 環境負荷ガスや有害ガスの放出は燃焼時に生 じ，燃焼・溶融・精錬時に大きくエネルギが生じる。した がって, 従来のリサイクル手法から, 熱消費を伴うプロセ ス（燃焼・溶融・精鍊）を除去すれば，このような問題を 解決できると考えられる。ここで，はんだペーストは金属 粒子と有機物成分で構成されている。すなわち，廃はんだ ペースト中から金属粒子を取りだすことが可能となれば, 有害ガスの放出やエネルギ消費を抑制できると考えられ る。言うまでもなく，有機物成分は有機溶媒に溶解する。 したがって，廃はんだペースト中の有機成分を有機溶媒で 溶解除去すれば，廃はんだペースト中のはんだ合金粒子を 簡単に回収可能であると考えられる。

そこで本研究では，廃はんだペースト中に含まれるはん だ合金粒子を有機溶媒で回収するための技術開発について 検討した。

\section{2. 実 験}

廃はんだペースト $10 \mathrm{~g}$ に対し各種有機溶剤（アセトン, メタノール, エタノール, トルエン） $10 \mathrm{ml}$ を添加・混合 し2分間超音波洗浄処理を行った。洗浄後, 上澄みの有機 溶媒を除去し，粒子のみを回収した。洗浄回数による表面 洗浄力の評価を行うため, 洗浄操作を 1 回から複数回繰り 返し行い粒子を回収した。回収した粒子に対し常温大気圧 下で乾燥を行い, 洗浄荗として使用した有機溶媒を完全に 気化させ粉末状試料を回収した。

回収粒子表面上の有機系残留量はフーリエ変換赤外分光 光度計 (Fourier Transform InfraRed spectrometer, Thermo Scientific, AVATAR 360 FTIR, 以下FT-IR）により分析し た。粒子表面状態は走査型電子顕微鏡（Scaning Electron Microscopy，日立製作所，S-4100，以下SEM)，元素の同 定はエネルギ分散型X線分析装置（Energy Dispersive X-ray microanalysis，エダックス・ジャパン, Genesis XM1，以 下SEM-EDX）を用いて評価した。粒子最表面の状態分析 はX線光電子分光装置 (X-ray Photoelectron Spectroscopy, 島津製作所，ESCA3400，以下，XPS）を使用し，粒子表面 上における Br 3d 領域や $\mathrm{Sn} 3 \mathrm{~d}$ 領域, $\mathrm{Ag}$ 3d 領域, $\mathrm{Cu} 2 \mathrm{p}$ 領 域の結合エネルギ測定を行った。また粒子表面から深さ方 向における結合エネルギの変化を測定するため, Arガスに よるエッチングを行った。エッチング時間は 5 秒から 35 秒, $\operatorname{Ar}$ ガスの圧力を $2 \times 10^{-2} \mathrm{~Pa}$ と設定した。

\section{3. 結果および考察}

洗浄操作に従って回収した粒子の FT-IR分析結果を Fig. 1 に示す。分析結果から 1 回の洗浄操作では粒子表面に有 機物由来のピークが観測されたが, 洗浄操作が 2 回以上で はピークが極端に減少することが確認された。この結果か ら，洗浄操作を 2 回以上行うことで粒子表面の有機物がほ ぼ除去されることが示唆される。

回収粒子のSEM表面観察結果を Fig. 2 に示す。Fig. 2

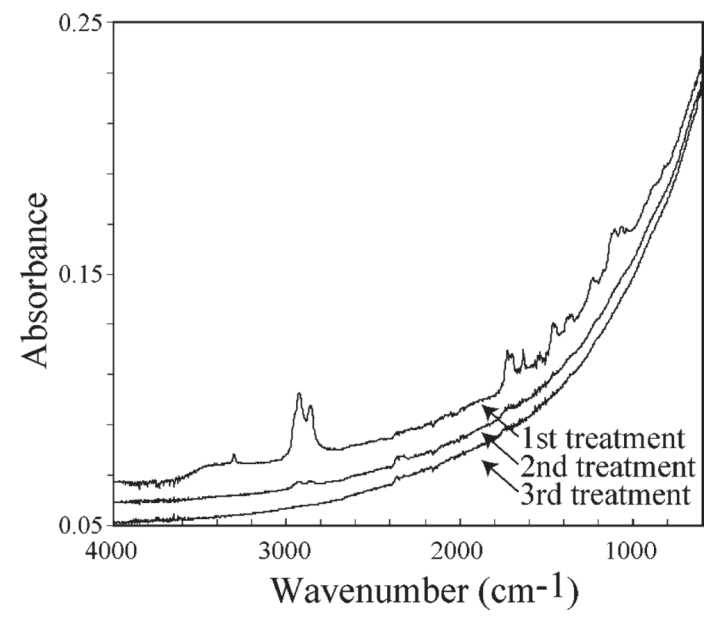

Fig. 1 FT-IR profiles of recovered solder particles

(A) 1st treatment
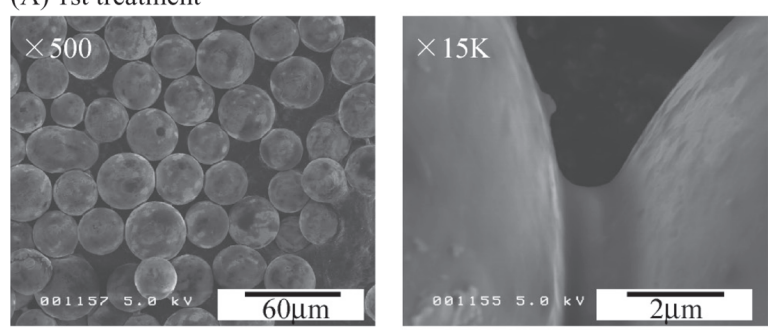

(B) 2nd treatment
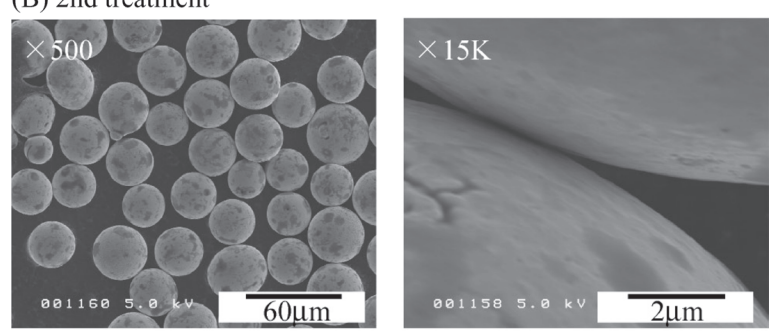

(C) 3rd treatment
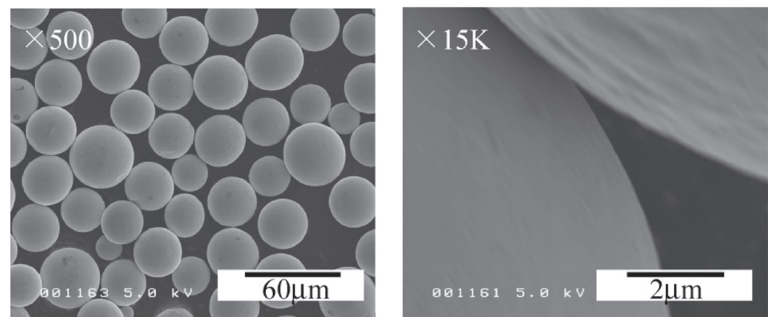

Fig. 2 SEM image of recovered solder particles as the function of treatment time, (A) 1st treatment, (B) 2nd treatment, (C) 3rd treatment 

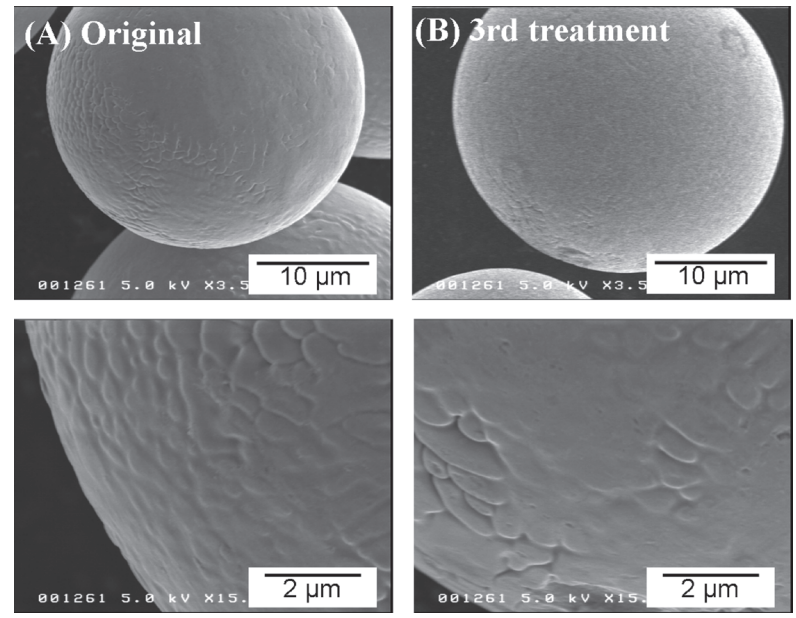

Fig. 3 SEM image of (A) original solder particles and (B) recovered solder particles (3rd treatment)

(A) (B) (C) はそれぞれ，1回，2回および3回の洗浄操作 後の粒子のSEM観察結果を示している。観察結果より 1 回, 2 回の洗浄操作では粒子表面上に堆積物が残存するこ とがわかる。一方, 3 回以上の洗浄操作を行った場合は, 清浄な表面であることか観察された。これらの粒子の表面 をSEM-EDXで分析したところ，Fig. 2 (A) 中に観測され る粒子表面の斑点部位や接合部位は炭素元素を大量に含ん でいることが観測された。一方, 3 回洗浄操作を行った粒 子の表面からの炭素は検出限界以下であった。以上ょり, 有機溶媒によるはんだペーストの洗浄操作を 3 回以上行う ことで, 粒子表面上に存在する有機物はほぼ除去可能であ ることを確認した。なお，温度による洗浄効果の違いは観 測されなかった。

3 回の洗浄操作を行ったはんだ合金粒子（以下，回収粒 子と表記）と未使用のはんだ合金粒子（Sn96.5\%-Ag3.0\%Cu0.5\%粒子，原料粒子と表記）の SEM観察結果を Fig. 3 に示す。図より，両者の大きさや形態に大きな恋化は観測 されないことがわかるが, 回收粒子の表面の方が原料粒子 の表面よりも滑らかであることがわかる。すなわち，はん だペーストが製造され廃棄されるまでの間に，表面状態が わずかに変化していることがわかる。そこで, 次に, XPS を用いて，それぞれの粒子の表面状態分析を行った。

原料粒子と回収粒子のXPSによる粒子表面分析結果を Fig. 4 に示す。本研究で用いたはんだ合金の組成は Sn96.5\%-Ag3.0\%-Cu0.5\%であることから, Sn 3d 領域, Ag $3 \mathrm{~d}$ 領域および Cu 2p 領域における結合エネルギ状態の分析 を行ったが，本論文では顕著な差が観測された Sn 3d 領域 の分析結果を示す。なお，図中 (A) は原料粒子を用いた 場合であり，(B) は回収粒子の結果を示している。また， 試料の $\operatorname{Ar} ッ チ ン ク ゙$ 前後の分析を行い, 深さ方向分析結 果（デプスプロファイル）として図示している。すなわ ち, 最上段が未処理の試料表面の分析結果であり, 次段が 5秒間の $\operatorname{Ar}$ エッチング後試料表面の分析結果, 再下段が
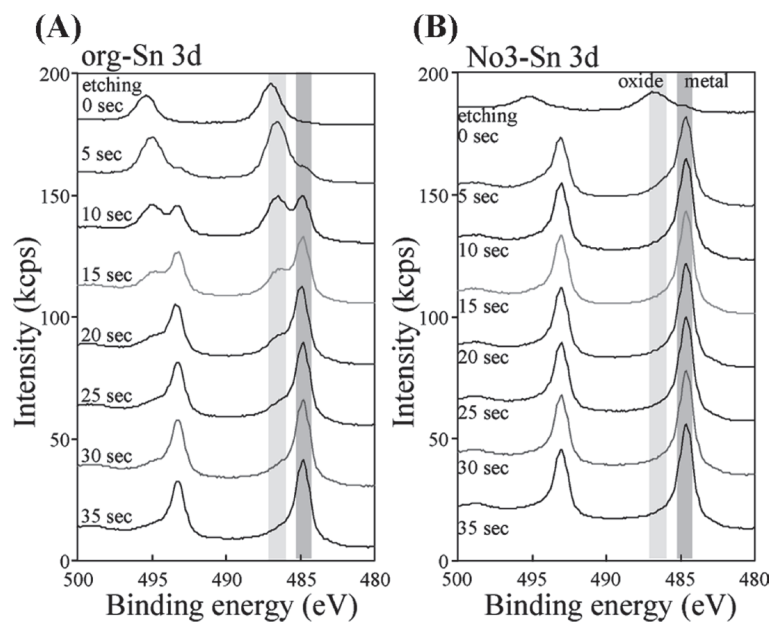

Fig. 4 XPS profiles at Sn $3 d$ region of $(A)$ original solder particle and $(B)$ recycled solder particle (3rd treatment), with and without Ar etching (0-35 s)

35秒間の $\operatorname{Ar}$ エッチング後試料表面の分析結果，を示して いる。

Fig. 4 (A) に示した原料粒子の Sn 3d 領域でのXPS分析 結果からは $\mathrm{SnO}_{2}$ の結合エネルギ $\left(486.7 \mathrm{eV}^{9,10)}\right)$ と一致す る位置のみにピークが観測されたのに対し，Fig. 4 (B) の

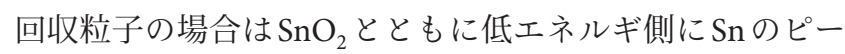
ク $\left(485 \mathrm{eV}^{10)}\right)$ が観測された。いずれの粒子の場合も, $\mathrm{Ar}$ エッチング時間の増加とともに $\mathrm{SnO}_{2}$ のピーク強度は減少 し Snのピーク強度は増加するが, $\mathrm{SnO}_{2}$ のピークが非検出

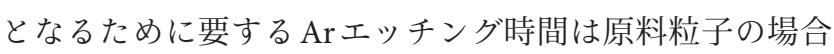
は約 30 秒であったのに対し回収粒子の場合は5 秒以下で あった。この結果は, 回収粒子の場合, 表面に存在する酸 化物層の厚さか減少していることを意味している。

以上の回収粒子の表面分析結果より, 製造から廃棄の過 程において，はんだ合金粒子表面上のスズ酸化物層の厚さ が著しく低減していることが明らかとなった。はんだペー スト中には，金属粒子とともにさまざまな有機化合物が含 まれているが，その中のハロゲン化合物は次式に従って金 属粒子表面の酸化被膜層と反応し，はんだ合金微粒子表面 の酸化被膜厚さを低減させた可能性が高いと考えられ $3^{11)}$ 。

Halogen surfactant $+3 \mathrm{SnO}_{2} \rightarrow 3 \mathrm{SnBr}_{2}+\mathrm{R}-6 \mathrm{O}$

すなわち，酸化物厚さが低減する代わりに，粒子表面に は八ロゲン化合物が存在する可能性が考えられる。そこ で, 回収粒子表面の Br 3d 領域におけるXPS分析を行っ た。なお，はんだペースト調整に用いたハロゲン活性剤お よび臭化スズ（和光純薬社製, 試薬特級, 以下, $\mathrm{SnBr}_{2}$ と 表記）を比較対照用の標準物質として用いた。

Fig. 5 に示す Br領域のXPS 分析結果より, 回収粒子表面

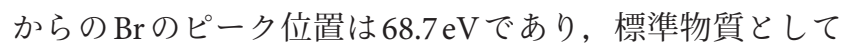
用いたハロゲン活性剤および臭化スズのそれはそれぞれ 

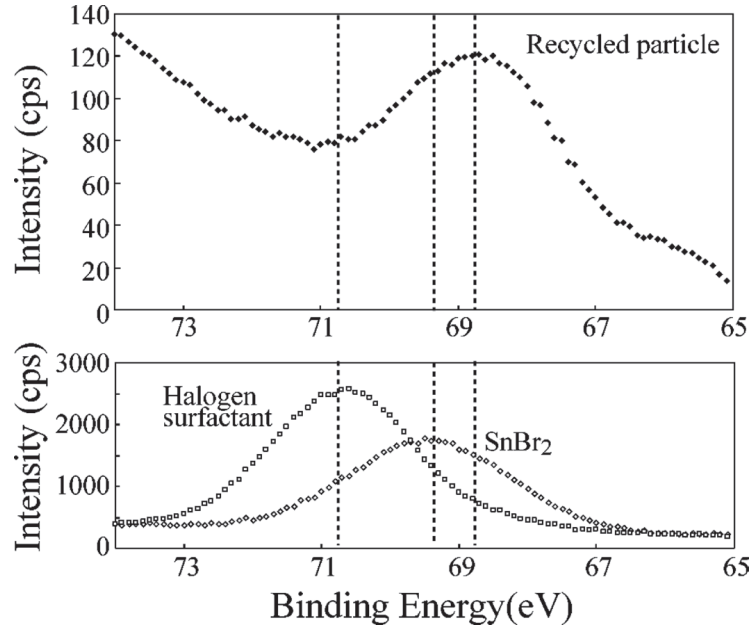

Fig. 5 XPS profiles at $\mathrm{Br} 3 \mathrm{~d}$ region of recycled solder particles and halogen surfactant used in this experiment and $\mathrm{SnBr}_{2}$

$70.7 \mathrm{eV}$ および $69.4 \mathrm{eV}$ となった。この結果から粒子表面に 存在する物質は明らかにハロゲン活性剂と異なることがわ かる。式 (1) の反応式より, 回収粒子表面から検出された $\mathrm{Br}$ 源は $\mathrm{SnBr}_{2}$ であると考えられるが，XPSの測定結果から は回収粒子と標準サンプルとして測定した $\mathrm{SnBr}_{2}$ のピーク 位置と若干異なる。これはXPS分析における表面内殼準 位シフト (surface core level shift) によるものであると考え られる ${ }^{12), 13)}$ 。例えば，Riffeらはタングステンの表層にお けるピーク位置はバルク体におけるピーク位置と相違があ ることを報告しており，これは表層とバルク体内部におけ る結合手数の相違に起因したピーク位置変動であると述べ ている ${ }^{14)}$ 。表面内殼準位シフトがある場合には， $\pm 0.5 \mathrm{eV}$ 程度ピーク位置が変動する ${ }^{12), 13)}$ 。以上より, 本研究で用 いた回収粒子は表面近傍に臭素化合物として存在し，標準 サンプルとして用いた $\mathrm{SnBr}_{2}$ （バルク体）とは若干ピーク にずれが生じる可能性がある。ここで，JIS Z 3197 8.1.4.2 に従った手法にて測定された，3回の繰り返し洗浄処理を 行った回収粒子表面上の残留ハロゲン量は $184 \mathrm{ppm}$ であっ た。本研究で用いたはんだ合金粒子（直径 $32 \mu \mathrm{m}$ ）の表面 積や，表面が酸化スズであること，さらに $\mathrm{SnO}_{2}$ の密度や 格子定数などを考慮すると，粒子表面に存在するスズと臭 素の比率は $\mathrm{Sn}: \mathrm{Br}=1: 2.77 \sim 4.12$ の範囲となると計算され る。これははんだ粒子を単純な真球として計算している が，SEM観察結果からもわかるように，実際のはんだ合 金粒子表面には多数の凹凸が存在するため, 真球よりも表 面積が大きい。以上の結果を考慮すると，回収粒子表面は $\mathrm{SnBr}_{2}$ に近い組成の $\mathrm{Sn}-\mathrm{Br}$ 化合物により覆われているもの と考えられる。

以上の結果より，有機溶媒を用いて廃はんだペーストか らはんだ合金粒子を回収することが可能であることが示さ れた。回収粒子と原料粒子はサイズや形に大きな相違はな いが, 回収粒子の表面酸化被膜が低減し最表面が $S n-B r$ 化
(A) new powders
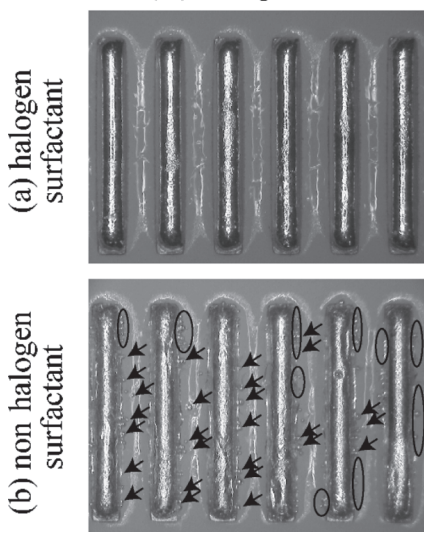

Fig. 6 Optical photograph of the integrated circuit board by using the solder paste synthesized from (A) new solder powders and (B) recycled powders (3rd treatment) with (a) halogen surfactant and (b) non halogen surfactant

合物化していること，また，表面がわずかに平滑化してい ること，がわかる。すなわち，回収粒子と原料粒子の状態 は若干異なっている。一般的なリサイクルにおいて，回収 品の特性は新品の特性と比較して低下することが多い。そ こで, 本手法により回収された粒子の電子実装材料として の特性を評価した。

回収した粒子と未使用粒子を，それぞれフラックスと混 合しははんだペーストを作製した。なお，フラックスは八 ロゲン活性剤含有, 非含有の両方を使用した。Fig. 6 (A) および (B) は，それぞれ原料粒子および回収粒子を用い て調製したはんだペーストによる電子実装結果（光学顕微 鏡写真) である。図の上段 (a) では八ロゲン活性剤含有フ ラックス, 下段 (b) は八ロゲン活性剤非含有フラックス, を用いてはんだペーストを作製した。なお，配線部の間隔 （ピッチ）が $0.4 \mathrm{~mm}$ の基板を用いた。

電子実装試験結果より，原料粒子とハロゲン活性剂非含 有フラックスで調製したはんだペーストの場合，図中に示 すように多数の欠陷部位（はんだボール）が生成している ことがわかる。このようなはんだボールは配線間のショー 卜を引き起こすため, このような部位が多数生成する組み 合わせは実用に供することはできない。一方，回収粒子を 用いた場合，ハロゲン活性剂非含有のフラックスとの組み 合わせであっても，はんだボールの生成がない極めて良好 な電子実装特性を示した。すなわち，回収粒子は，その表 面上に存在する約 $180 \mathrm{ppm}$ の $\mathrm{Br}$ 量のみで電子実装を可能 とする，極めて高い特性を示すことが明らかとなった。以 上より，本手法で回収した粒子は，新品粒子と同等以上の 電子実装特性を示すと判断できる。

\section{4. 結 論}

廃はんだペースト中に含まれるはんだ合金粒子を有機溶 
媒で回収するための技術開発について検討した。その結 果, 廃はんだペーストからトルエンで 3 回以上超音波洗浄 を行うことで，有機物成分と金属成分の完全な分離，およ びはんだ合金粒子のみの回収が可能であることが明らかと なった。

原料である粒子および回収した粒子表面をSEM観察し た結果，両者の大きさに大きな変化は観測されなかった が，回収粒子表面では原料粒子と比較し表面が滑らかに なっていることを確認した。これは，はんだペーストの製 造から廃棄過程に扔いて表面状態が変化したことに起因す ると考えられる。XPSによるSn 3d 領域の分析結果から， 原料粒子表面と比較して, 回収粒子表面の酸化被膜が著し く低減していることが観測され，さらにBr 3d領域におけ る分析結果より回収粒子表面には $\mathrm{SnBr}_{2}$ に近いピークをも つ Br化合物の存在が確認された。分析結果および表面酸 化物とハロゲン活性剂との反応式より，はんだペースト製 造〜廃棄過程で表面酸化物と八ロゲン活性剤による化学 反応により酸化被膜が除去され，表面にはスズーハロゲン 化合物が形成されていることが明らかとなった。回収した 粒子をフラックスと混合しはんだペースト化し電子実装材 料としての特性評価を行った結果，回収した粒子は原料粒 子と同等以上の実装特性を有することが明らかとなった。

以上より, 有機溶媒を用いることで, 大量に廃棄されて いる廃はんだペーストから粒子を回収可能であり，回収さ れた粒子は新品粒子と同等以上の特性を発現可能であると 考えられる。

\section{謝 辞}

この研究の一部は科学研究費補助金若手 (A) (22681009) の助成を受けたものである。

（2012.2.9-受理）

\section{文献}

1) I. Ohnuma, X. J. Liu, H. Ohtani, and K. Ishida: "Thermodynamic Database for Phase Diagrams in Micro-Soldering Alloys," J. Electron. Mater., Vol. 28, pp. 1164-1171, 1999

2) A. Bondi: "The Spreading of Liquid Metals on Solid SurfacesSurface Chemistry of High-Energy Substances," Chem. Rev., Vol. 52, pp. 417-458, 1953

3) 堀口俊一編: “鉛,”労働科学研究所出版部, 1993

4) P. W. Price, B. J. Rathcke, and D. A. Gentry: "Lead in Terrestrial Arthropods: Evidence for Biological Concentration," Environmental Entomology, Vol. 3, p. 3, 1974

5) M. Hansen: "Constitution of Binary Alloys," McGraw-Hill Book Co., Inc., New York, 1958

6）電子情報技術産業協会 (JEITA) 鉛フリーはんだ実装編集委 員会編：“鉛フリーはんだ実装技術,”コロナ社, 2003
7) for example, M. E. Loomans, S. Vaynman, G. Ghosh, et al.: "Investigation of Multicomponent Lead-Free Solders," J. Electron. Mater., Vol. 23, No. 8, pp. 741-746, 1994

8) JIS規格 JIS Z 3001 分類：ろう接 万う接材料 番号 : 4209 用語：はんだペースト

9) H. Willemen, et al.: "ESCA Study of Tin-Compounds," Inorg. Chim. Acta, Vol. 34, pp. 175-180, 1979

10) W. E. Morgan and J. R. Vanwazer: "Binding-Energy Shifts in X-Ray Photoelectron Spectra of a Series of Related Group IV-A Compounds," J. Phys. Chem., Vol. 77, pp. 964-969, 1973

11) D. L. D. Chung et al.: "Materials for Electronic Packaging," Butterworth-Heinemann, London, U.K., 1995

12) N. Mortensson and A. Nilsson: "On the Origin of Core-Level Binding Energy Shifts," J. Electron Spectrosc. Relat. Phenom., Vol. 75, pp. 209-223, 1995

13) S. Hüfner: "Photoelectron Spectroscopy," Springer, US (1995)

14) D. M. Riffe, G. K. Wertheim, and P. H. Citrin: "Alkali-Metal Adsorbates on W(110)-Ionic, Covalent, or Metallic," Phys. Rev. Lett., Vol. 64, pp. 571-574, 1990

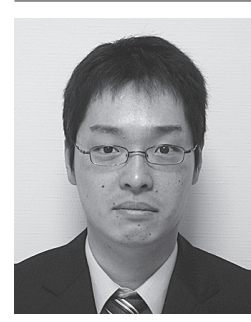

著者紹介

田中武志（たなか たけし）

東北大学大学院環境科学研究科 博士課程学生

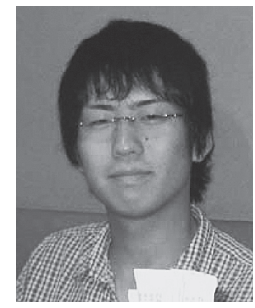

島田陽三（しまだ ようぞう） 東北大学大学院環境科学研究科 修士課程学生 (現：JAPEX)

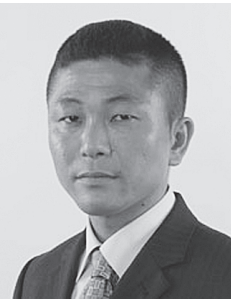

高橋英志（たかはし ひでゆき） 東北大学大学院環境科学研究科 准教授

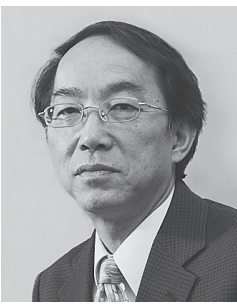

田路和幸（とうじ かずゆき） 東北大学大学院環境科学研究科 教授 